\title{
Change in the dynamics of salinity and water quality of an island estuary by the discharge of effluents
}

\section{Alteração na dinâmica da salinidade e na qualidade das águas de um estuário insular pelo lançamento de efluentes}

\author{
Claudinei José Rodrigues ${ }^{1}$ (D), Davide Franco ${ }^{2}$, Alessandra Larissa D’Oliveira Fonseca ${ }^{2}$ (D), Nei Kavaguichi Leite ${ }^{2}$ (D), \\ Luis Hamilton Pospissil Garbossa ${ }^{3}$ (D) \& Aichely Rodrigues da Silva ${ }^{4}$ (D) \\ ${ }^{1}$ Instituto Chico Mendes de Conservação da Biodiversidade, Florianópolis, SC, Brasil \\ ${ }^{2}$ Universidade Federal de Santa Catarina, Florianópolis, SC, Brasil \\ ${ }^{3}$ Empresa de Pesquisa Agropecuária e Extensão Rural de Santa Catarina, Florianópolis, SC, Brasil \\ ${ }^{4}$ Universidade Federal do Maranhão, Grajaú, MA, Brasil \\ E-mails: nei.icmbio@gmail.com (CJR), d.franco.ocean@gmail.com (DF), alarissa.fonseca@gmail.com (ALOF), nei.leite@ufsc.br (NKL), \\ garbossa@gmail.com (LHPG), aichely@gmail.com (ARS)
}

Received: February 15, 2021 - Revised: May 29, 2021 - Accepted: June 29, 2021

\begin{abstract}
Anthropic changes in coastal watersheds affect the quantity and quality of water in estuaries. Based on an analytical model of saline intrusion and load balance, we have evaluated the effects of effluent discharge (mean of $285 \mathrm{~L} \cdot \mathrm{s}^{-1}$ and peak of $495 \mathrm{~L} \cdot \mathrm{s}^{-1}$ ) from a wastewater treatment plant (WWTP) in an island estuary. Saline intrusion at low tide, without actual anthropic discharge, will increase by $22 \%$, whereas with increasing discharge, reductions of $16 \%$ and $28 \%$. The reduction of saline intrusion may affect biogeochemical processes and the distribution of species in regions further up the estuary. When the WWTP reaches the mean projected discharge, it will increase its BOD and phosphorus loads by $90 \%$ and $82 \%$, respectively, in relation to the current load. With the increase of WWTP discharge, there will be an expansion of hypoxic and anoxic conditions over the current areas, worsening the condition of this already jeopardized estuary. For the WWTP to lead to the expected environmental gains, it is necessary to consider the carrying capacity of the receiving body.
\end{abstract}

Keywords: Estuary; Salt intrusion; Carrying capacity.

\section{RESUMO}

As alterações antrópicas nas bacias hidrográficas costeiras afetam a quantidade e a qualidade da água dos estuários. A partir de um modelo analítico de intrusão salina e do balanço de cargas, avaliamos os efeitos da descarga de efluentes projetada para uma estação de tratamento de esgoto (ETE) (média de $285 \mathrm{~L} \cdot \mathrm{s}^{-1}$ e pico de $495 \mathrm{~L} \cdot \mathrm{s}^{-1}$ ) em um estuário insular. A intrusão salina na maré baixa, sem descarga antrópica, aumentará em $22 \%$, ao passo que com o aumento da descarga haverá reduções de $16 \%$ e $28 \%$. A redução da intrusão salina poderá afetará processos biogeoquímicos e a distribuição de espécies em regiões mais a montante do estuário. Quando a ETE atingir sua vazão média projetada, aumentará suas cargas de DBO e fósforo em $90 \%$ e $82 \%$, respectivamente, em relação à carga atual. Com o aumento da vazão da ETE haverá ampliação das atuais áreas em condição de hipóxica e anóxica, piorando a situação atual deste estuário já comprometido. Para que a ETE traga os ganhos ambientais esperados é necessário considerar a capacidade suporte do corpo receptor.

Palavras-chave: Estuário; Intrusão salina; Capacidade suporte. 


\section{INTRODUCTION}

Aquatic environments in coastal zones (CZ) are under strong pressure from anthropic activities due to the high population density in these areas (Pinto-Coelho \& Havens, 2015). The low sanitation rates in the $\mathrm{CZ}$ represent one of the main impact factors on the water environment in this region. The estuarine region is a transitional environment between river and sea, being influenced by oceanic and watershed processes, commonly receiving domestic effluents from urban centers. In this context, wastewater treatment plants - WWTP are important structures in urban areas, but they also promote transposition of watersheds, when the supply water comes from a different basin from the one in which the effluent is released, increasing the water input in the receiving body.

Freshwater discharge and seawater inflow, associated with mixing and transport processes in the estuarine mixing zone, provide ideal conditions for the occurrence of biogeochemical processes and sedimentation of suspended particulate matter, increasing the productivity of these environments (Miranda et al., 2002; Bianchi, 2007). Freshwater inputs from anthropogenic sources have the potential to cause changes in the salinity gradient, nutrient, dissolved oxygen, and sediment dynamics in estuarine environments (Kimmerer, 2002), factors that influence the distribution and welfare of estuarine species (Gillson, 2011; Blaber, 2000; Bussell et al., 2008). The salinity gradient in estuaries is an indicator of mixing processes between freshwater from river and saline waters from the adjacent sea, but it is also a key process of saline flocculation. Regions of low salinity favor the flocculation of suspended clay from river drainage, serving as nucleation points for adhesion of inorganic and biological materials, with the growth of the flocs, sedimentation occurs (Bianchi, 2007; Wolanski \& Elliott, 2015). The tidal movements in estuaries promote the resuspension of these sediments in certain areas and deposition in others, favoring the absorption of nutrients, metals, and dissolved organic matter present in the water column, representing an efficient process of pollutant removal in estuaries (Stumm \& Morgan, 1996; Bianchi, 2007).

Commonly, the self-depuration processes of rivers and estuaries in the CZ are insufficient to absorb the load generated by the anthropic activity. Thus, WWTPs are essential facilities for mitigating the impacts caused by human settlements (Morrison et al., 2011; Cloern et al., 2016). However, depending on the design characteristics of the WWTP and the carrying capacity of the water environment, effluents can bring negative impacts to their receiving bodies, by raising the organic matter and nutrient loads (Haggard et al., 2005; Silva et al., 2016; Cabral et al., 2019). The input of organic matter and nutrients from anthropogenic sources has been a major problem in estuaries around the world (Kennish, 2002; Cloern et al., 2016; Bianchi, 2007). Organic matter, commonly assessed in terms of BOD, in addition to consuming dissolved oxygen in aerobic oxidation process, can also drastically interfere with the community of estuarine organisms, reducing local biodiversity (McLusky \& Elliott, 2006). Effluent discharge has drastically affected nutrient fluxes (nitrogen and phosphorus) in aquatic environments (Van Drecht et al., 2009; Mekonnen \& Hoekstra, 2018). Causing, by eutrophication, the expansion of the occurrence, intensity, and duration of hypoxic conditions in coastal waters worldwide (Testa \& Kemp, 2011), resulting in changes in community structure, loss of biodiversity, and modifications in the metabolism of the environment (Diaz \& Rosenberg, 2008; Scherner et al., 2013). In many urbanized estuaries, effluents are the main sources of nutrients (phosphorus and nitrogen) and organic matter (Pereira Filho \& Rörig, 2016; Silva et al., 2016), directly impacting the functioning of the environment and its uses.

In this study, we have a hypothesis that the increase of effluent discharge from a WW'P in an island estuary will promote the retraction of the saline intrusion and reduce the quality of the estuarine water. To evaluate the effect of effluent discharge on water quality, the load balance was used and in the evaluation of saline intrusion from the estuary the model described by Savenije (1986, 2005) was used. This model was applied in 35 estuaries in four continents (Savenije, 2020). However, this study is the first to use this model in Brazil, in an insular estuary of reduced dimensions, with the low fluvial flow, and applied in the evaluation of the reduction of the saline intrusion by the discharge of the effluents of a WWTP.

\section{MATERIALS AND METHODS}

\section{Field of study}

The Papaquara River watershed, located in the North of Santa Catarina Island, in the city of Florianópolis - SC (Figure 1), has an area of $32 \mathrm{~km}^{2}$, having its catchment outlet in the Ratones River, inside the Carijós Ecological Station, protected areas of category full protection (Law 9,985/00 art. 8). The climate of the region is characterized as humid subtropical Cfa (Peel et al., 2007) with rainfall well distributed throughout the year, with the month of February presenting the highest volumes of accumulated rainfall (198 mm, varying 190-210 mm) and June, the lowest volumes (75 mm, varying 70-90 mm), according to Ramos et al. (2009). The region has a semidiurnal astronomical tidal regime with microtidal amplitude with an average of $0.7 \mathrm{~m}$ ranging from 0.4 to $1.2 \mathrm{~m}$ (Truccolo et al., 2006). The meteorological components have a strong effect on tide, northeastern winds exert an under elevation and south winds over elevation at tide levels, low-frequency south wind events can exert up to $1 \mathrm{~m}$ over an elevation on the astronomical tide (Truccolo et al., 2006).

The fixed population estimated in 2017 for Papaquara watershed is approximately 15,500 inhabitants (Prosul, 2012), but this population triples during summer vacation (Guarda, 2012), which starts in the second half of December and lasts until the end of Carnival, the second half of February. The population of Papaquara watershed receives treated water from an aquifer located in another watershed. The public sewage system serves only $0.9 \mathrm{~km}^{2}$ of the Papaquara watershed, which corresponds to approximately $22 \%$ of the population living there (Figure 1). The remaining population has individual treatment systems (septic systems) with final disposal in the soil and in rainwater drainage system, which represents an estimated flow of $23.5 \mathrm{~L} \cdot \mathrm{s}^{-1}$. WWTP currently has an average design capacity of $285 \mathrm{~L} \cdot \mathrm{s}^{-1}$ and a maximum hourly flow of $495 \mathrm{~L} \cdot \mathrm{s}^{-1}$ (Steinwandter, 2019). The average flow rate of WWTP has its value increased due to the maximum daily flow coefficient and the maximum hourly flow coefficient resulting in maximum hourly flow or peak flow rate (Associação Brasileira de Normas Técnicas, 1986). The operating annual average for 2017 


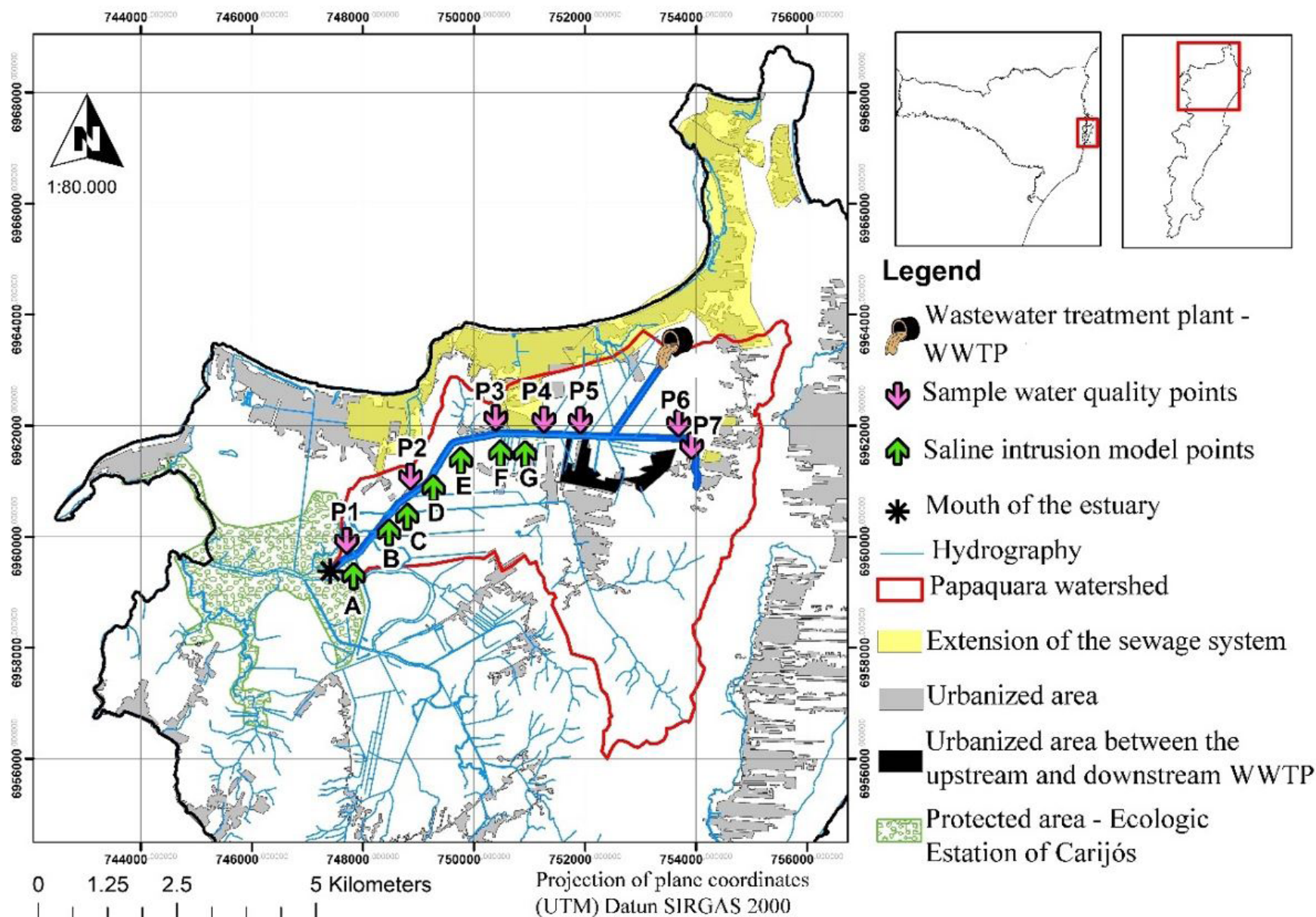

Figure 1. Papaquara River basin, coverage of the public sewage system, urbanized areas, location of the sampling point for water quality assessment, and points for obtaining data from the saltwater intrusion model.

was $135 \mathrm{~L} \cdot \mathrm{s}^{-1}$, with the lowest average recorded in July $95 \mathrm{~L} \cdot \mathrm{s}^{-1}$ and the highest average in January $201 \mathrm{~L} \cdot \mathrm{s}^{-1}$ of the same year (Instituto Chico Mendes de Conservação da Biodiversidade, 2011). The treated effluent is discharged into a drainage channel, which travels $1.8 \mathrm{~km}$ until it flows into the Papaquara River (Figure 1). The population covered by WWTP is approximately 40,000, but only $8.5 \%$ of this population live in the Papaquara watershed.

\section{Sampling}

The analytical model of saline intrusion was generated form data of width, depth (portable echo sounder, Laylin Associates, model SM5), water velocity (flow meter, OTT Hydromet, model OT'T MF pro) and calibrate from data of salinity (manual refractometer, Alfakit, model 201bp). The data was obtained in seven sampling stations along the Papaquara River estuary (Figure 1), onboard of a vessel, in the high tide condition associated with the winds of the South quadrant (wind velocity, maximum of 10.9 and average of $1.9 \mathrm{~m} \cdot \mathrm{s}^{-1}$ ), that promote higher meteorological tide, on August 24, 2015. The average flow for WWTP this day $\left(85 \mathrm{~L} \cdot \mathrm{s}^{-1}\right)$ was used to calibrate the saline intrusion model. For validation of the model, another water salinity measurements from five sampling date (from October 2013 to April 2014) were carried out at five sampling station in three tides moments on different days. The average tidal heights at the time of sampling, for validation, were $0.3 \mathrm{~m}$ (low tide), $0.5 \mathrm{~m}$ (medium tide) and $0.9 \mathrm{~m}$ (high tide).

The water quality was evaluated in seven sampling stations along the Papaquara River (P1 to P7), in addition to the location where the final effluent from the WWTP is discharged (Figure 1), during nine sampling campaigns from August 2014 to February 2015. The water quality parameters determined were: salinity (manual refractometer, Alfakit, model 201bp), dissolved oxygen - DO (Associação Brasileira de Normas Técnicas, 1988), biochemical oxygen demand - BOD (Associação Brasileira de Normas Técnicas1992a), and total phosphorus - TP (Associação Brasileira de Normas Técnicas, 1992b). The percentage of dissolved oxygen saturation (DO \%) was calculated as a function of temperature and salinity according to Chapra (1997).

\section{Flow estimate}

In the study area, there are no gauging stations, so the river flow was estimated using the equations described in the Santa Catarina State flow regionalization study (Santa Catarina, 2006). The long term average flow rate $\left(\mathrm{Q}_{\mathrm{MLT}}\right)$ or long period flow rate of a river basin corresponding to the average of the annual 
average flows or the average of the averages, being estimated by Equation 1 (Santa Catarina, 2006).

$Q_{M L T}=\left(9.393 \times 10^{-4} \cdot P^{0.362} \cdot A D^{1.092}\right) \cdot 1000$

where $Q_{M L T}$ is long-term average flow $\left(\mathrm{L} \cdot \mathrm{s}^{-1}\right) ; P$ is the precipitation $\left(\mathrm{mm} \cdot\right.$ year $\left.{ }^{-1}\right)$ and $A D$ the drainage area $\left(\mathrm{km}^{2}\right)$.

The flow-duration curve represents the relations between the flows of a river with the probability that its occurrence equals or exceeds this flow value (Tucci, 2002). The flow-duration curve is obtained by calculating the average long-term flow rate (Equation 1) multiplied by the appropriate percentile coefficient $(K p)$ for each region (Santa Catarina, 2006).

Garbossa \& Pinheiro (2015), when analyzing the uncertainty of the equations proposed by Santa Catarina, (2006) in the continental and island basins that flows into the Santa Catarina Island Bays, found an average deviation of $-24 \%$ in frequencies close to $\mathrm{Q}_{50}$ and $10 \%$ in $\mathrm{Q}_{\mathrm{MLT}}$ for basins with an area above $10.3 \mathrm{~km}^{2}$. Despite limitations in the application of the flow regionalization methodology for small basins (Silveira et al., 1998), the equations proposed by Santa Catarina, (2006) are still a good alternative due to lack of continuous monitoring in the region.

Historical annual mean precipitation, of $1.543 .9 \mathrm{~mm} \cdot \mathrm{year}^{-1}$ (Ramos, et al., 2009) and the Papaquara watershed area, of $32.0 \mathrm{~km}^{2}$, were applied at Equation 1. Also, the values $707 \mathrm{~L} \cdot \mathrm{s}^{-1}$; $496 \mathrm{~L} \cdot \mathrm{s}^{-1}$ and $342 \mathrm{~L} \cdot \mathrm{s}^{-1}$ were considered as $\mathrm{Q}_{25}, \mathrm{Q}_{50}$ and $\mathrm{Q}_{75}$, respectively. For the estimation of the load water balance in the river, the river flow $\left(\mathrm{Q}_{50}\right)$ of the Papaquara river was estimated upstream and downstream from the WWTP effluent discharge point; considering a drainage area of $6.1 \mathrm{~km}^{2}$ for the upstream point (P6 in Figure 1) and $10.6 \mathrm{~km}^{2}$ for the downstream point from the WWTP (P5 Figure 1), the values of $\mathrm{Q}_{50}$ were 44.5 and $153 \mathrm{~L} \cdot \mathrm{s}^{-1}$, respectively. The flow of the WWTP was obtained by an ultrasonic level meter installed at the entrance of the raw effluent in the plant (Nivelco brand, model Ecotrek).

\section{Saline intrusion}

The one-dimensional analytical model of salinity developed by Savenije $(1986,2005)$ estimates the longitudinal profiles of salinity in alluvial estuaries, considering geometric parameters of the estuary and its salinity. The main parameters used in the model were detailed in Figure 2.

In a steady-state situation, the partial derivative as a function of time in the salt balance equation is equal to zero. Savenije (2005), considering as constant the fluvial flow (Qf) and the area of section $(A)$, defined the salt balance equation as:

$$
S-S_{f}=\frac{-A}{\left|Q_{f}\right|} D \frac{d S}{d x}
$$

where: $S$ : Salinity; $S_{f}$ the fluvial salinity; $A$ is the area of the section; $Q_{f}$ the fluvial flow and $D$ the longitudinal dispersion coefficient.

Relationship between salinity and dispersion coefficient, based on the work of Van der Burg (1972), defined by:

$$
\frac{d D}{d x}=-K \frac{\left|Q_{f}\right|}{A}
$$

where $K$ is the Van der Burgh coefficient.

The longitudinal distribution of salinity can be expressed by replacing Equation 2 in 3 and integrating it and considering the fluvial salinity as zero, we have:

$$
S_{x}=S_{0} \cdot\left(\frac{D_{x}}{D_{0}}\right)^{\frac{1}{K}}
$$

where $S_{x}$ is the salinity at a point in the estuary (psu); $S_{0}$ the salinity at the mouth of the estuary (psu); $D_{x}$ the coefficient of longitudinal dispersion at a point in the estuary $\left(\mathrm{m}^{2} \cdot \mathrm{s}^{-1}\right)$ and $D_{0}$ the coefficient of longitudinal dispersion at the mouth of the estuary $\left(\mathrm{m}^{2} \cdot \mathrm{s}^{-1}\right)$.

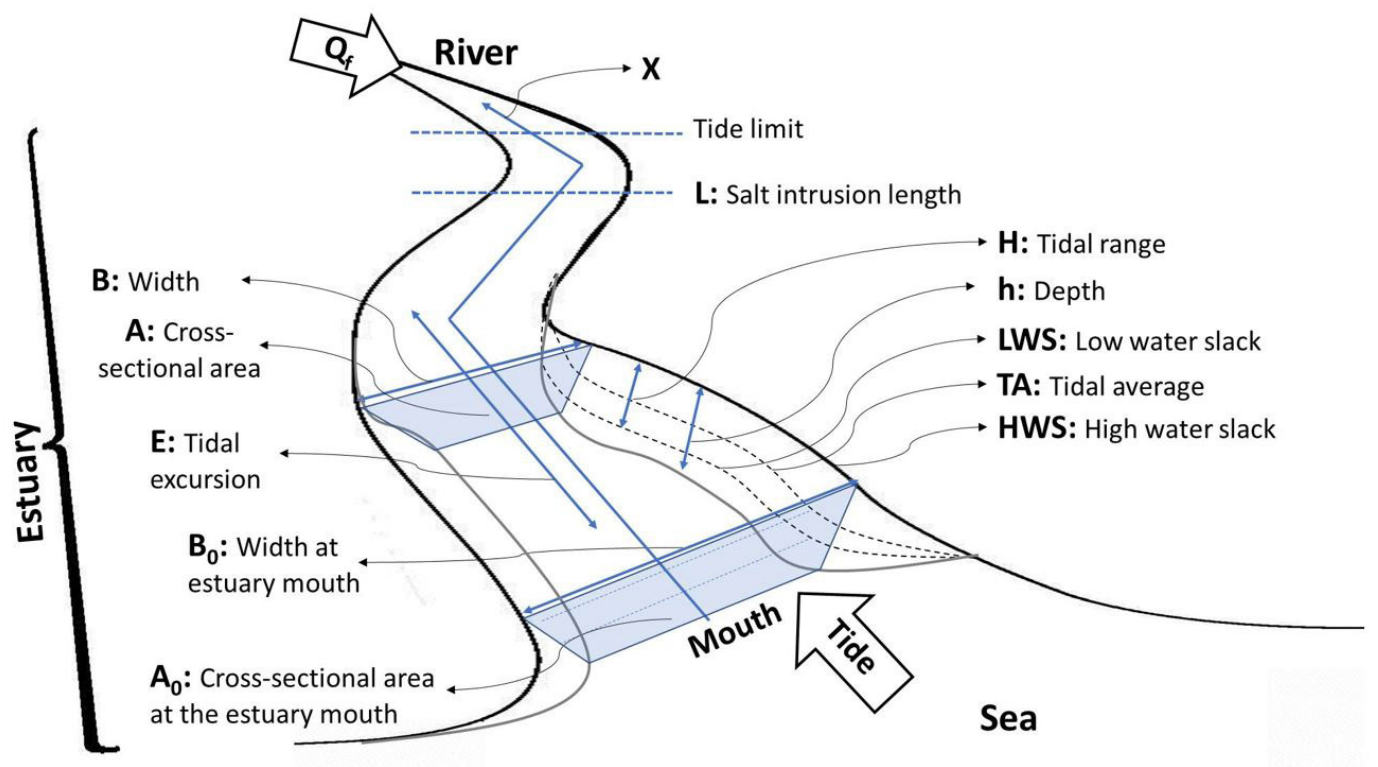

Figure 2. Outline of the definition of the parameters of the saline intrusion model in an alluvial estuary. 
In estuaries of alluvial plains the cross-sectional area and the width (Figure 2) can be described by exponential functions along the longitudinal axis of the estuary (Savenije, 2005), according to the following equations:

$$
\begin{aligned}
& A=A_{0} \cdot e^{\left(\frac{-x}{a}\right)} \\
& B=B_{0} \cdot e^{\left(\frac{-x}{b}\right)}
\end{aligned}
$$

where $a$ is the cross-sectional convergence length (m) and $b$ the convergence length of the stream width $(\mathrm{m})$.

Substituting the exponential relationship of Equation 5 in Equation 3 and integrating we have:

$$
D_{x}=D_{0} \cdot\left\{1-\beta\left[e^{\left(\frac{x}{a}\right)}-1\right]\right\}
$$

Being: $\beta=\frac{K \cdot a}{\alpha_{0} \cdot A_{0}}$

$\alpha_{0}=\frac{-D_{0}}{Q_{f}}$

where $\beta$ : rate of dispersion reduction rate, adimensional and $\alpha_{0}$ : coefficient of the mixture in the mouth of the estuary in $\left(\mathrm{m}^{-1}\right)$.

When the salinity of a given point in the estuary $(S x)$ is equal to the fluvial salinity $(S f)$, the longitudinal dispersion coefficient will be equal to zero $\left(D_{x}=0\right)$, rearranging Equation 7, we can estimate the salt intrusion length $(L)$.

$$
L=\operatorname{aln}\left(\frac{1}{\beta}+1\right)
$$

In the calibration process, the parameters that can be adjusted are the Van der Burgh coefficient $(K)$ and the parameter $\alpha_{0}$, in the condition of high water slack. The Van der Burgh coefficient was estimated according to Gisen et al. (2015a).

The longitudinal dispersion coefficient at the mouth of the estuary $\left(D_{0}\right)$ is an essential parameter for the model and there is no way to measure it directly, being calculated for the condition of high water slack, according to Deynoot, (2011).

$D_{0}^{H W S}=1400 \cdot \frac{h_{0} \cdot E^{0.5}}{a} \cdot \sqrt{\frac{\Delta \rho}{\rho} \cdot g \cdot \frac{Q_{f} \cdot T}{B_{0}}}$

where $D_{0}^{H W S}$ is the longitudinal dispersion coefficient at the estuary mouth in the high water slack $\left(\mathrm{m}^{2} \cdot \mathrm{s}^{-1}\right) ; h_{0}$ is the depth of the estuary at the mouth $(1.6 \mathrm{~m}) ; E$ is tidal excursion $(2,742.69$ $\mathrm{m})$; $\varrho$ the density $\left(\mathrm{kg} \cdot \mathrm{m}^{-3}\right) ; \Delta \varrho$ the difference in density; $g$ the acceleration of gravity $\left(\mathrm{m} \cdot \mathrm{s}^{-2}\right.$ ) and $T$ the tidal period (43082 s).

After calibration of the model in the high water slack condition, the $\mathrm{D}_{0}$ is estimated for average tide and low water slack, using Equations 13 and 14.
$D_{0}^{T A}=D^{H W S}\left(\frac{E}{2}\right) \cdot e^{\left(\frac{-E}{2 \cdot a}\right)}$

$D_{0}^{L W S}=D^{H W S}(E) \cdot e^{\left(\frac{-E}{a}\right)}$

where $D_{0}^{T A}$ is the longitudinal dispersion coefficient at the mouth of the estuary at tidal average $\left(\mathrm{m}^{2} \cdot \mathrm{s}^{-1}\right)$ and $D_{0}^{\text {LWS }}$ the longitudinal dispersion coefficient at the mouth of the estuary at low water slack $\left(\mathrm{m}^{2} \cdot \mathrm{s}^{-1}\right)$.

Analysis of the saline intrusion model

The steps of calibration, verification, sensitivity analysis, and validation of the model are fundamental for the consistency between the results predicted by the model and the actual values of the system studied (Fleck et al., 2013). For the model calibration, data obtained on the day, August 24, 2015, in high tide condition, was used, the calculated $\mathrm{K}(0.43)$ was kept fixed and the parameter $\alpha_{0}$ (Equation 9) was adjusted, varying the calculated value upwards and downwards until the mean square errors (RMSE), as calculated according to Equation 14, were reduced by maximum. The normality of the distribution of errors and their homoscedasticity were evaluated by the Shapiro-Wilk test $(\mathrm{p}>0.05)$ and the Breusch-Pagan test $(\mathrm{p}>0.05)$, respectively. The index of agreement $(d r)$ used, proposed by Willmott et al. (2011), is expressed in Equation 15.

$R M S E=\sqrt{\frac{\sum(\text { Yest }- \text { Yobs })^{2}}{n}}$

$d r=1-\frac{\sum \mid \text { Yest }- \text { Yobs } \mid}{2 . \sum \mid \text { Yobs }- \text { Yobs }_{\text {médio }} \mid}$

where RMSE is the mean root of the quadratic errors; Yest the values estimated by the model; Yobs the values observed in the field; $n$ the number of observations; Yobs ${ }_{\text {med }}$ the mean of the values observed in the field and $d r$ the index of agreement.

In a sensitivity analysis, the model response was tested using variations of $30 \%$ in the calibrated value of the parameter $\alpha_{0}$ and variations of $50 \%$ in the calculated Van der Burgh (K) coefficient. In the model validation, water salinity data was used at three times of the tide on different days. The average tidal heights at the time of these samplings, for validation, were $22 / 01 / 14$ low tide $(0.3 \mathrm{~m})$, $23 / 10 / 13 ; 06 / 12 / 13$ and $16 / 04 / 14$ average tide $(0.5 \mathrm{~m})$; high tide of $14 / 02 / 14(0.9 \mathrm{~m})$.

\section{Scenarios}

Law 14,975/09 of the State of Santa Catarina establishes conditions for the discharge of effluents into estuaries and other water bodies, where all assessments must be made for the most unfavorable conditions to the environment (maximum effluent flow) to order to ensure quality standards foresee for the body of water (art. 177, VII). Based on the legal prerogative, three 
scenarios were applied to the calibrated model: I) distribution of salinity in the Papaquara estuary without the contribution of anthropic flow; II) distribution of salinity with the flow for which the WWTP was designed, i.e. $285 \mathrm{~L} \cdot \mathrm{s}^{-1}$; III) distribution of salinity with the WWTP under a maximum hourly flow or peak design flow, of $495 \mathrm{~L} \cdot \mathrm{s}^{-1}$.

\section{RESULTS}

\section{Water quality}

The average concentration of BOD observed at the WWTP outlet was $35.5 \mathrm{mg} \cdot \mathrm{L}^{-1}$, with variations between minimum and maximum of 2.8 and $137 \mathrm{mg} \cdot \mathrm{L}^{-1}$, respectively. The mean total phosphorus concentration in the effluent of the WWTP was $3.0 \mathrm{mg} \cdot \mathrm{L}^{-1}$, varying between 0.9 and $6.9 \mathrm{mg} \cdot \mathrm{L}^{-1}$ (Figure 3). The concentrations of TP and BOD in P5 (downstream of WWTP, Figure 1) present the mean values of 0.8 and $7.0 \mathrm{mg} \cdot \mathrm{L}^{-1}$, respectively. In the same P5, the lowest DO \% values were observed (Figure 3), with a mean value of 3.5\% saturation. Low levels of DO were quantified in the whole estuary, being $55 \%$ of the samples characterized as hypoxic $\left(<2 \mathrm{mg} \cdot \mathrm{L}^{-1}\right.$, or approximately $30 \%$ saturation, Rabalais et al., 2010) and $20 \%$ of them with anoxic $(\mathrm{N}=63)$.

The concentrations of TP and DO \% showed a significant linear correlation with salinity downstream of WWTP (P5 until P1), as Figure 4.

The average flow observed at the WWTP was $143 \mathrm{~L} \cdot \mathrm{s}^{-1}$, with variations between minimum and maximum of 68 and $187 \mathrm{~L} \cdot \mathrm{s}^{-1}$, respectively. The BOD load increased elevenfold from upstream to downstream, from 0.18 to $1.98 \mathrm{gO}_{2} \cdot \mathrm{s}^{-1}$ and the total phosphorus load increased fifteenfold, from 0.016 upstream to $0.239 \mathrm{gP} \cdot \mathrm{s}^{-1}$ downstream (Figure 5).

Considering the average flow and concentration of the final effluent of the WWTP in terms of DBO and TP, it was possible to calculate the current and future load of the WWTP in scenarios II and III (flow of $285 \mathrm{~L} \cdot \mathrm{s}^{-1}$ and $495 \mathrm{~L} \cdot \mathrm{s}^{-1}$ ), according

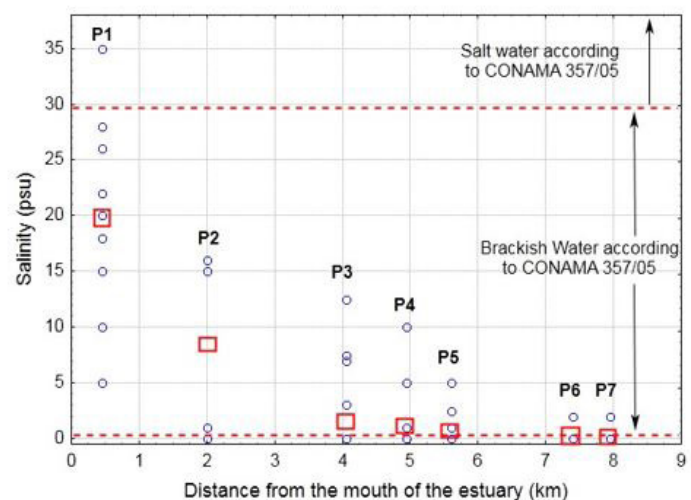

A

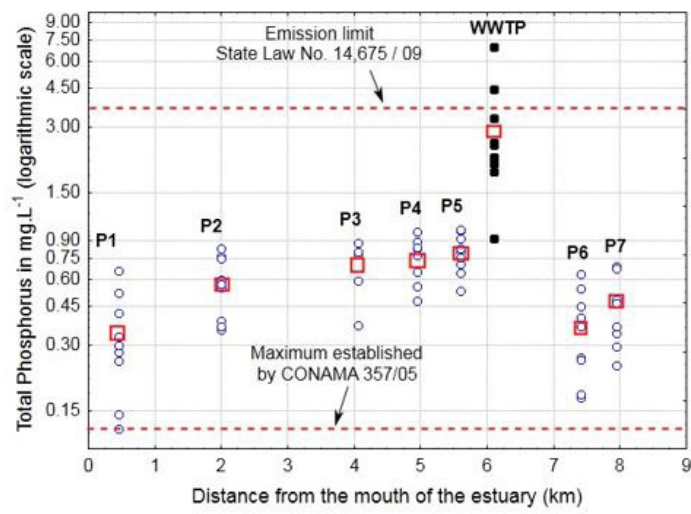

C

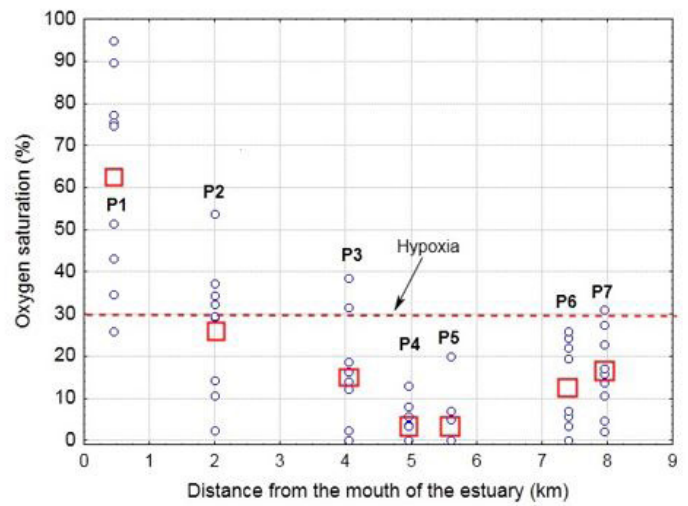

B

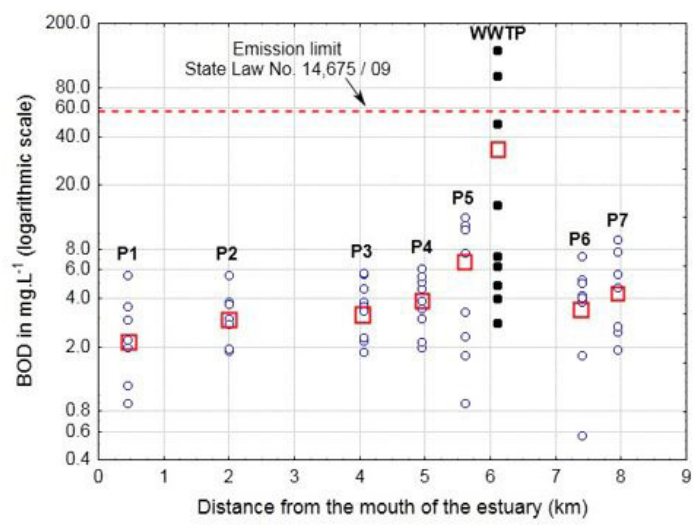

$\mathrm{D}$

Figure 3. Dispersion chart of the parameters: salinity (A); the percentage of oxygen saturation (B); total phosphorus (C) and BOD (D) in the waters of the Papaquara River and the effluent treated by WWTP. Black points represent the concentration in the final effluent of the WWTP, empty points the concentration in the Papaquara River, red squares correspond to the average values of the sample points. 


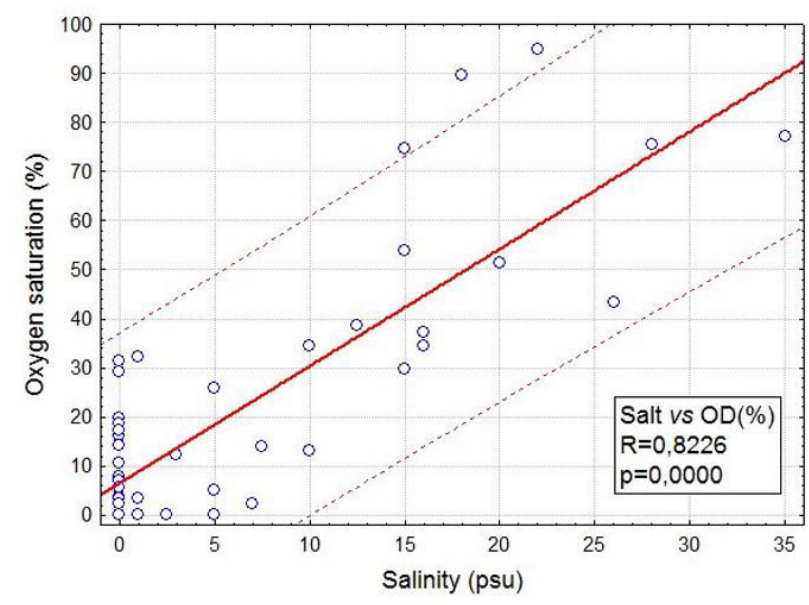

A

Figure 4. Linear regression between DO $\%$ salinity and TP with a 95\% prediction interval and correlation coefficient. Oxygen Saturation and Salinity (A) and Total Phosphorus and Salinity (B).

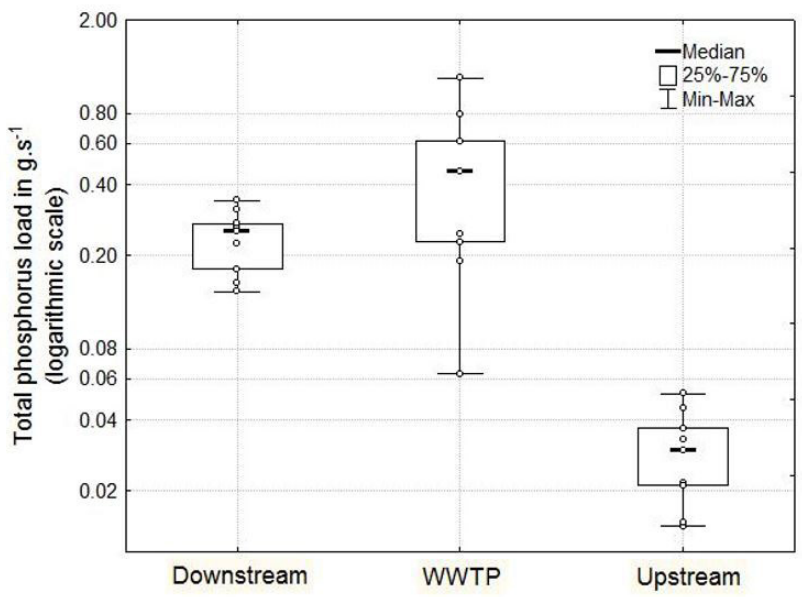

A

Figure 5. Box Plot, median, upper and lower quartiles, and maximum-minimum values of total phosphorus loads (A) and DBO (B), at WWTP and points upstream and downstream of WWTP on Papaquara River.

to Table 1. For peak flow, maximum hourly flow, scenario III, the DBO and TP load of WWTP can increase by $224 \%$ and $219 \%$, respectively, concerning the current load (Table 1).

\section{Saline intrusion}

During the calibration of the saline intrusion model, the $\alpha_{0}$ parameter was adjusted and used the WWTP flow rate of the data acquisition period, $85 \mathrm{~L} \cdot \mathrm{s}^{-1}$ and $\mathrm{Q}_{50}$ of $\operatorname{river}\left(496 \mathrm{~L} \cdot \mathrm{s}^{-1}\right)$ the diffuse flow of the population not served by the sewage system was not considered. The value calculated for the parameter $\alpha_{0}$ was $370 \mathrm{~m}^{-1}$ (Equation 9), resulting in an RMSE of 2.4. In the

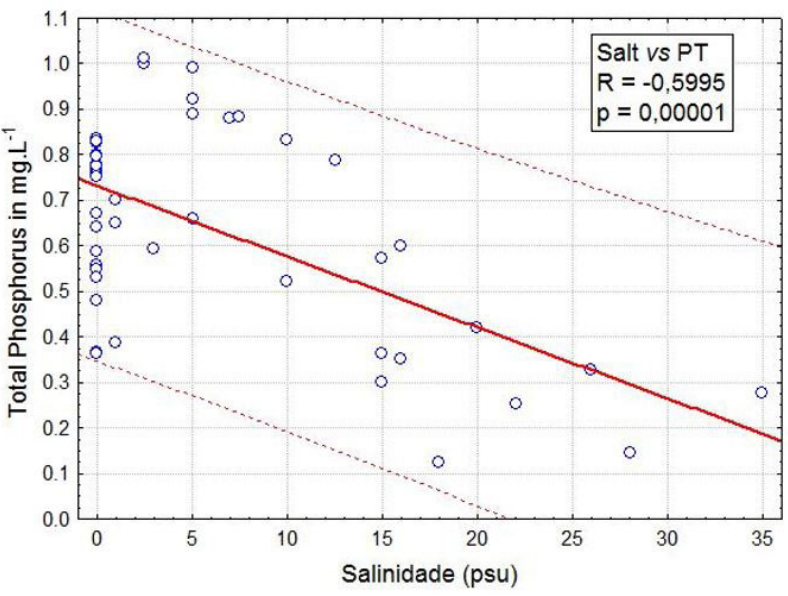

B

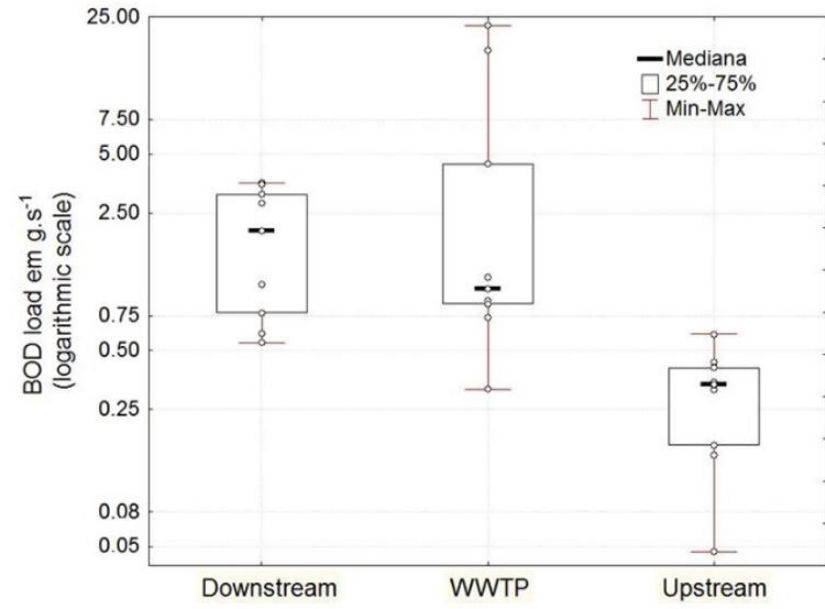

B

calibration process, we tested values of $\alpha_{0}$ between 220 and $500 \mathrm{~m}^{-1}$, with intervals of $5 \mathrm{~m}^{-1}$, being observed the lowest value of RMSE (1.1) with $\alpha_{0}$ of $295 \mathrm{~m}^{-1}$, (Figure 6).

The residuals of the calibrated model showed normal distribution and homoscedasticity ( $p>0.05$ ). The good performance of the model is demonstrated by the high index of agreement $(d r)$ which was 0.85 . In the sensitivity test the values of $\alpha_{0}$ used were 206 and 383 (30\% of the calibrated value) and of the parameters $\mathrm{K} 0.21$ and 0.64 (50\% of 0.43 , value calculated), as shown in Figure 7 . The sensitivity test suggests that the model is more sensitive to the parameter $\alpha_{0}$ than the coefficient $K$ (Figure 7). In the validation, the same flow of the calibration was used. The model was consistent during the validation, as observed in 
Figure 8 , obtaining high indexes of agreement $(d r)$, which varied between 0.84 and 0.92 .

The saline intrusion model developed by Savenije (1986, 2005) has been applied in estuaries with very distinct physical characteristics of the Papaquara River estuary. The data available in Savenije (2020), for 35 estuaries out of 86 collections, demonstrate that the model has already been applied in environments with river flow rates ranging from 2,000 to $316,000 \mathrm{~L} \cdot \mathrm{s}^{-1}$, mixing coefficient at the estuary mouth $\left(\alpha_{0}\right)$, ranging from 0.13 to $48 \mathrm{~m}^{-1}$, and saline intrusion at high tide $\left(L^{H W S}\right)$ between 10 to $160 \mathrm{~km}$. The flow of Papaquara presents average fluvial flows of $496 \mathrm{~L} \cdot \mathrm{s}^{-1}$, mixing coefficient of $295 \mathrm{~m}^{-1}$, and saline intrusion at a high tide of $9 \mathrm{~km}$. This model has been applied for the description of saline intrusion in estuaries (Ervine et al., 2007; Zhang et al., 2011;

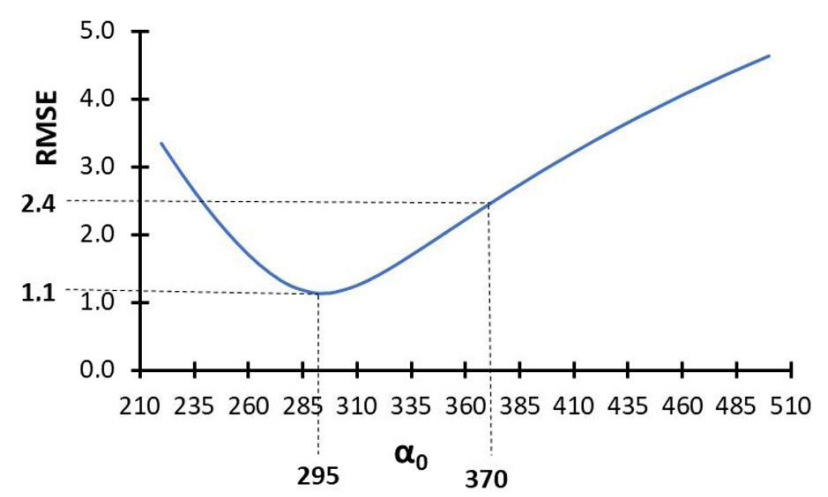

Figure 6. RMSE result during the calibration process of the model, highlighting the RMSE values with $\alpha_{0}$ calculated and calibrated.
Gisen et al., 2015b), determination of freshwater discharge in estuaries (Nguyen et al., 2008) and in the prediction of increased intrusion due consumptive use of water (Cai et al., 2015; Abdullah, 2017). Even facing these differences, the model proved to be robust, with coherent results such as those observed under field conditions (Figure 8), thus enabling reliable forecasts. However, further studies should be carried out, with the objective of evaluating the effect of daily fluctuations in the flow of WWTP in the saline intrusion of Papaquara, considering that the flow of WWTP is of the same order of magnitude as the river flow. The model developed by Savenije (1986, 2005), besides being easy to implement (executable in electronic spreadsheets), requires few input data and proved to be very useful to understand the estuarine functioning and to predict changes in the saline gradient, facing changes in the freshwater input.

\section{Scenarios}

From the proposed scenarios, a progressive reduction of the saline gradient was observed with the increase of anthropic flow (Figure 9). The reduction of saline intrusion in different scenarios varied between 11 and $28 \%$, as shown in Table 2 .

The average design capacity flow and the maximum hourly flow (peak flow) of the WWTP could raise the river flow of the estuary by 57 and 100\% respectively. In scenarios II and III, of 781 and $991 \mathrm{~L} \cdot \mathrm{s}^{-1}$, respectively, this flow can also be expected under natural conditions, but with a low probability of occurrence $\left(\mathrm{Q}_{20}\right.$ and $\left.\mathrm{Q}_{10}\right)$. However, the contribution of treated effluent by the WWTP has as main feature, the continuous discharge in the estuary.

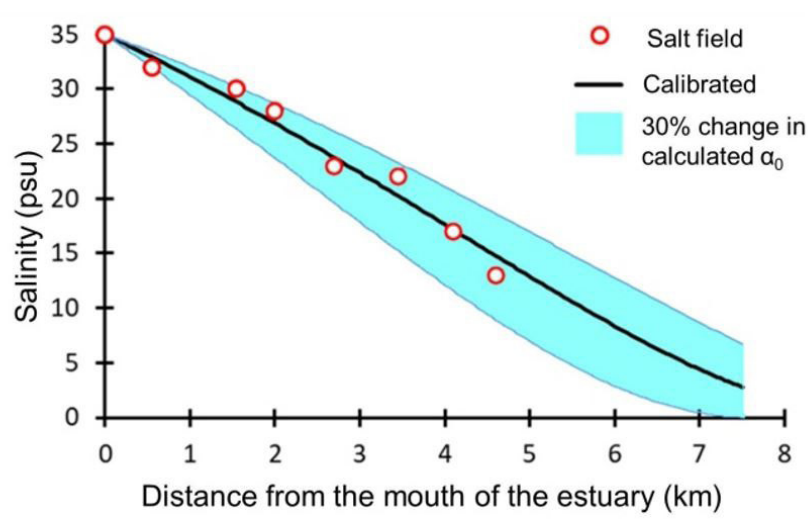

A

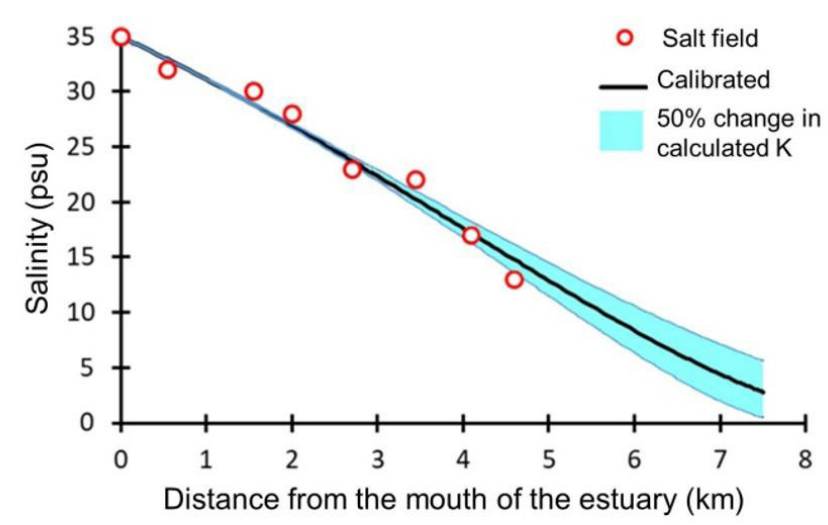

B

Figure 7. Model sensitivity to variations of parameters $\alpha_{0}(\mathrm{~A})$ and the coefficient $K(\mathrm{~B})$.

Table 1. Load of the current WWTP and the estimated one when the WWTP reaches the projected flows.

\begin{tabular}{lccc}
\hline \multicolumn{1}{c}{ Type of flow from WWTP } & Flow $\left(\mathbf{L} \cdot \mathbf{s}^{-1}\right)$ & Load DBO $\left(\mathrm{gO}_{2} \cdot \mathbf{s}^{-1}\right)$ & Load PT $\left(\mathrm{gP} \cdot \mathbf{s}^{-1}\right)$ \\
\hline Actual (mean) & 143 & 5.42 & 0.46 \\
Mean Projected (scenario II) & 285 & 10.13 & 0.84 \\
Maximum Projected (scenario III) & 495 & 17.59 & 1.47 \\
\hline
\end{tabular}


Table 2. Current saline intrusion and the three different scenarios in $\mathrm{km}$ and their modifications in percentage terms related to the current condition.

\begin{tabular}{|c|c|c|c|c|c|c|c|}
\hline \multirow[t]{2}{*}{ Condition } & $\begin{array}{l}\text { Current } \\
\mathrm{Q}_{\text {WwTP }}\end{array}$ & \multicolumn{2}{|c|}{ Scenario I $\mathbf{Q}_{\mathrm{WWTP}}$ : } & \multicolumn{2}{|c|}{ Scenario II $Q_{\text {WWTP }}$ : } & \multicolumn{2}{|c|}{ Scenario III $Q_{\text {WWTP }}$ : } \\
\hline & $143 \mathrm{~L} \cdot \mathrm{s}^{-1}$ & \multicolumn{2}{|c|}{$0 \mathrm{~L} \cdot \mathrm{s}^{-1}$} & \multicolumn{2}{|c|}{$285 \mathrm{~L} \cdot \mathrm{s}^{-1}$} & \multicolumn{2}{|c|}{$495 \mathrm{~L} \cdot \mathrm{s}^{-1}$} \\
\hline High Tide & $9.0 \mathrm{~km}$ & $10.2 \mathrm{~km}$ & $13 \%$ & $8.0 \mathrm{~km}$ & $-11 \%$ & $7.0 \mathrm{~km}$ & $-22 \%$ \\
\hline Average Tide & $6.5 \mathrm{~km}$ & $7.5 \mathrm{~km}$ & $15 \%$ & $5.7 \mathrm{~km}$ & $-12 \%$ & $4.8 \mathrm{~km}$ & $-26 \%$ \\
\hline Low Tide & $3.2 \mathrm{~km}$ & $3.9 \mathrm{~km}$ & $22 \%$ & $2.7 \mathrm{~km}$ & $-16 \%$ & $2.3 \mathrm{~km}$ & $-28 \%$ \\
\hline
\end{tabular}

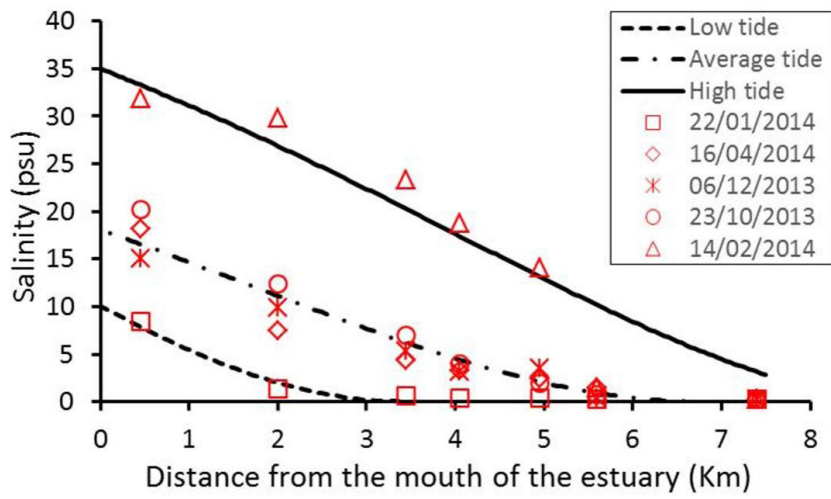

Figure 8. Curves resulting from the salinity distribution model in high tide, average tide and low tide conditions; associated with the validation of the model with field data other than those used in calibration.

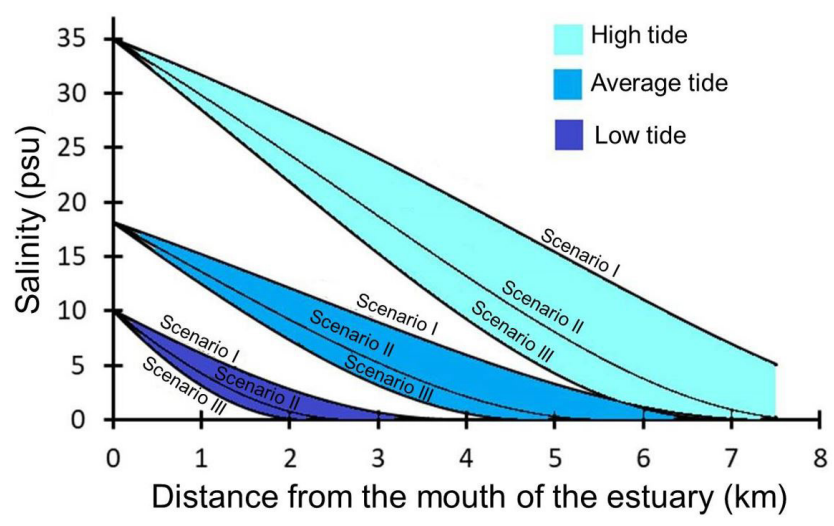

Figure 9. Salinity distribution in the three different scenarios and tidal conditions.

\section{DISCUSSION}

An increase of the anthropic effluent loaded projected from WWTP in the Papaquara River will decrease the saline intrusion, concomitantly, will increase the negative effect from pollutants. The reduction in saline intrusion (see Figure 9 and Table 2) may lead to changes in the physical dynamics (sediment flow), chemical (contribution of nutrients and organic matter), and biological (distribution and survival of species) of the estuaries (Kimmerer, 2002; Montagna et al., 2003; Bussell et al., 2008; Gillson, 2011). This reduction affects the occurrence of saline flocculation in upstream regions of the estuary. Saline flocculation is an important phenomenon in the self-depuration process of estuarine waters, adsorbing dissolved substances (Stumm \& Morgan, 1996; Bianchi, 2007; Wolanski \& Elliott, 2015). Perez et al. (2017) report that after the entry of the effluent from the WWTP into the Papaquara River, there was an increase in the total phosphorus, with predominance of the dissolved phosphorus fraction $(80 \%)$ in low salinity regions, and along the saline gradient, there was a reduction in total phosphorus concentration and a greater balance between dissolved and particulate phosphorus fractions (approximately 50\%). The authors attributed the increase in the fraction of particulate phosphorus to the adsorption processes during saline flocculation and in the resuspension of sediments by the movement of tides. Saline waters of the North Florianopolis Bay have higher oxygen concentrations and lower organic matter (BOD) and nutrient (phosphorus and nitrogen) concentrations when compared to the Papaquara River waters (Simonassi et al., 2010; Silva et al., 2016; Cabral et al., 2020). The inputs of these saline waters improve the water quality along the saline gradient of the estuary, as we can see in Figures 3 and 4, through adsorption and dilution processes. The reduction of saline intrusion indicates the decrease of saline water inflows in more upstream regions of the estuary (Table 2), affecting the self-depuration processes in these regions.

The CONAMA 357/05 resolution classifies waters according to their uses and typifies them according to their salinity, establishing maximum allowed concentrations of several parameters for each class and type. The modification of salinity in the estuary foreseen in this study will cause, besides the environmental effects, legal repercussions on the maximum allowed concentration of water quality parameters. Currently, the waters of the Papaquara River are provisionally classified as brackish class 1 and freshwater class 2 (resolutions CERH 01/08 and CONAMA 357/05 art. 42). According to the results of the model, currently, at high tide, the limit between these types of waters occurs $8.6 \mathrm{~km}$ upstream of the mouth of the estuary. In scenarios II and III this limit will be reduced to 7.3 and $6.3 \mathrm{~km}$ (Figure 9), that is, there will be a change in the classification of this stretch of the river, from brackish class 1 to freshwater class 2 . This stretch is where the entrance of the WWTP effluent occurs (Figure 1). In freshwater class 2, the maximum concentrations allowed for nitrogen compounds (nitrite, nitrate, ammonia) are higher than those allowed in brackish class 1 (CONAMA resolution 357/05 art. 15 and 22). Silva et al. (2016) registered average concentrations of ammonia nitrogen of $1.8 \mathrm{mg} \cdot \mathrm{L}^{-1}$ in brackish waters at $7.4 \mathrm{~km}$ from the mouth of the Papaquara River estuary, the maximum value allowed by the legislation being $0.4 \mathrm{mg} \cdot \mathrm{L}^{-1}$, configuring the disrespect to the standard. However, if this stretch is reclassified as freshwater class 2 , the maximum value allowed would be $3.7 \mathrm{mg} \cdot \mathrm{L}^{-1}$, considering the $\mathrm{pH}$ observed in the stretch by Silva (2015) and Rodrigues 
(2016), because for fresh waters, CONAMA 357/05 establishes the maximum concentration of ammoniacal nitrogen as a function of $\mathrm{pH}$. This change will further weaken the management of this water body that drains into a protected area. Disposal of treated effluents is discussed in the city through a working group with the participation of institutions at the Municipal, State and Federal levels (Municipal Decree n. 17,748/2017). For this group, water bodies that have a strong relationship with aquatic environments of protected areas of category full protection (Law 9,985/00 art. 8) should be classified as special class (Florianópolis, 2019), which would make the disposal of effluents unfeasible, even for treated disposals (CONAMA 430/11 art. 11). This is the situation of the Papaquara River, which flows to Ecological Station of Carijós, protected area of full protection type, and which receives effluents from WWTP (Figure 1), where its waters do not meet the quality standards by legislation (Figure 3).

The Brazilian environmental legislation prohibits that the entrance of effluents in a watercourse that alters its quality characteristics established for its class (CONAMA 430/11, art. 5). Despite the prohibition, the reality of rivers along the Brazilian coast shows that a load of organic matter, mainly from domestic sewage, is high and is promoting the degradation of estuaries (Aguiar et al., 2011; Souza \& Gastaldini, 2014; Cabral et al., 2020) and, consequently, violation of the standard. The situation in the Papaquara River is not different, the high concentrations of organic matter and nutrients, in conjunction to low concentrations of $\mathrm{OD}$ are at disagreement with the parameters established for its class (Figure 3). In the present study, $80 \%$ of the WWTP effluent samples presented BOD and TP concentrations below the maximum emission limit established by the Santa Catarina Law $\mathrm{n}^{\circ} 14$ 675/09 (art. 177, inc. V and XI). However, more than $90 \%$ of the dissolved oxygen and total phosphorus data observed in the Papaquara River are in disagreement with the legislation (Figure 3). The legislation for water body (CONAMA $357 / 05$, art. 21), establishes a minimum oxygen value of $5 \mathrm{mg} \cdot \mathrm{L}^{-1}$ (approximately $60-70 \%$ of saturation) and for the total phosphorus of $0.124 \mathrm{mg} \cdot \mathrm{L}^{-1}$.This paradoxical picture of compliance with emission standards and low quality of receiving water body can be explained by the reduced carrying capacity of the Papaquara River, which is understood as the capacity of the water body to receive a polluting load without compromising the quality of its waters, according to its framework (CONAMA 430/11 art. 4, inc. I). This reduced carrying capacity becomes evident when comparing the upstream and downstream loads of the WW'TP (Figure 5). Even if the quantified parameter concentrations in the effluent are below the maximum emission limit established by the Law (Figure 3), the volume launched is such that it exceeds the estuary's self-purification capacity, via biogeochemical (assimilation and adsorption) and physical (dilution) processes (Bianchi, 2007). With the increase in the load of the WWTP (Table 1), there will be an expansion of the current areas of the estuary that already suffer from hypoxia to anoxia (Figure 3B), impacting the functioning and uses of this environment. Poor water quality is been observed in other water bodies in the city even area covered by wastewater collection and treatment systems (Garbossa et al., 2017; Cabral et al., 2019). To avoid aggravating the situation, the working group established by City Decree n. 17,748/17, has been looking for alternatives for the final disposal of effluents generated in the city, considering alternatives such as submarine outfalls and indirect reuse through the recharge of aquifers (Florianópolis, 2019).

The European Community legislation does not establish fixed water quality values for estuarine environments, but guides a study of the typology of environments in each country and also establishes that the levels of effluent treatment must be defined according to the current quality of the waters of the receiving body and the anthropic pressure that the water body is submitted to (Silva et al., 2018). The role of WWTP in preventing and even reversing pollution in several coastal systems is notorious (Morrison et al., 2011; Cloern et al., 2016), since well operated and designed (Cabral et al., 2019), and, especially, that consider the carrying capacity of the body receiving the treated effluents. Thus, the evaluation of effluent discharged by the WWTP should be based more on the carrying capacity of the receiving water body (CONAMA 430/11, Art. 5) than on the maximum emission values.

\section{CONCLUSION}

With the increase in the flow and organic load launched by WWTP, there will be a reduction in saline intrusion and increase in the areas in hypoxic and anoxic conditions, confirming the hypothesis initially raised. This change will negative impacts for the local biota and biogeochemistry process in regions further up the estuary. For the WWTP to bring the expected environmental gains, it is more important to consider the carrying capacity of the receiving body than to the maximum emission values established.

\section{REFERENCES}

Abdullah, A. D. (2017). Modelling approaches to understand salinity variations in a bighly dynamic Tidal River: the case of the Shatt Al-Arab River (186 p). London: CRC Press. http://dx.doi.org/10.1201/9781315115948.

Aguiar, V. M. C., Baptista Neto, J. A., \& Rangel, C. M. (2011). Eutrophication and hypoxia in four streams discharging in Guanabara Bay, RJ, Brazil, a case study. Marine Pollution Bulletin, 62(8), 1915-1919. PMid:21708390. http://dx.doi.org/10.1016/j. marpolbul.2011.04.035.

Associação Brasileira de Normas Técnicas - ABNT. (1986). NBR 9.649: projeto de redes coletoras de esgoto sanitário. Rio de Janeiro: ABNT.

Associação Brasileira de Normas Técnicas - ABNT. (1988). NBR 10.559: águas: determinação de oxigênio dissolvido: método idométrico de Winkler e suas modificaşões. Rio de Janeiro: ABNT.

Associação Brasileira de Normas Técnicas - ABNT. (1992a). NBR 12.614: determinação da demanda bioquímica de oxigênio (DBO): método de incubação $\left(20^{\circ} \mathrm{C}\right.$, cinco dias). Rio de Janeiro: ABNT

Associação Brasileira de Normas Técnicas - ABNT. (1992b). NBR 12.772: água; determinação de fósforo. Rio de Janeiro: ABNT.

Bianchi, T. S. (2007). Biogeochemistry of estuaries (690 p.). Oxford: Oxford University Press. 
Blaber, S. J. M. (2000). Tropical estuarine fishes: ecology, exploration and conservation (Fish and Aquatic Resources Series, No. 7, 372 p.). Oxford: Blackwell Science. http://dx.doi.org/10.1002/9780470694985.

Bussell, J. A., Gidman, E. A., Causton, D. R., Gwynn-Jones, D., Malham, S. K., Jones, M. L. M., Reynolds, B., \& Seed, R. (2008). Changes in the immune response and metabolic fingerprint of the mussel, Mytilus edulis (Linnaeus) in response to lowered salinity and physical stress. Journal of Experimental Marine Biology and Ecology, 358(1), 78-85. http://dx.doi.org/10.1016/j.jembe.2008.01.018.

Cabral, A., Bercovich, M. V., \& Fonseca, A. (2019). Implications of poor-regulated wastewater treatment systems in the water quality and nutrient fluxes of a subtropical coastal lagoon. Regional Studies in Marine Science, 29, 100672. http://dx.doi.org/10.1016/j.rsma.2019.100672.

Cabral, A., Bonetti, C. H. C., Garbossa, L. H. P., Pereira-Filho, J., Besen, K., \& Fonseca, A. L. (2020). Water masses seasonality and meteorological patterns drive the biogeochemical processes of a subtropical and urbanized watershed-bay-shelf continuum. The Science of the Total Environment, 749, 141553. PMid:32829277. http://dx.doi.org/10.1016/j.scitotenv.2020.141553.

Cai, H., Savenije, H. H. G., \& Gisen, J. I. A. (2015). A coupled analytical model for salt intrusion and tides in convergent estuaries. Hydrological Sciences Journal, 61(2), 402-419. http://dx.doi.org/10. 1080/02626667.2015.1027206.

Chapra, S. C. (1997). Surface water-quality modeling (844 p.). Long Grove: Waveland Press.

Cloern, J., Abreu, P. C., Carstensen, J., Chauvaud, L., Elmgren, R., Grall, J., Greening, H., Johansson, J. O. R., Kahru, M., Sherwood, E. T., Xu, J., \& Yin, K. (2016). Human activities and climate variability drive fast-paced change across the world's estuarine-coastal ecosystems. Global Change Biology, 22(2), 513-529. PMid:26242490. http://dx.doi.org/10.1111/gcb.13059.

Deynoot, F. J. C. G. (2011). Analytical modeling of salt intrusion in the Kapuas Estuary (Thesis). Faculty of Civil Engineering and Geosciences, Delft University of Technology, Delft.

Diaz, R. J., \& Rosenberg, R. (2008). Spreading dead zones and consequences for marine ecosystems. Science, 321(5891), 926-929. PMid:18703733. http://dx.doi.org/10.1126/science.1156401.

Ervine, D. A., Bekic, D., \& Glasson, L. (2007). Vulnerability of two estuaries to flooding and salinity intrusion. Water Science and Technology: Water Supply, 7(2), 125-136. http://dx.doi.org/10.2166/ws.2007.047.

Fleck, L., Tavares, M. H. F., \& Eyng, E. (2013). Principais modelos matemáticos de qualidade da água e suas aplicações: uma revisão. Revista Eletrônica Científica Inovação e Tecnologia., 1(7), 46-61.

Florianópolis. Prefeitura Municipal - PMF. (2019). Estudo de concepcão do esgotamento sanitário em Florianópolis (203 p.). Retrieved in 2021, April 14, from http://www.pmf.sc.gov.br/arquivos/arquivos/ pdf/23_06_2020_14.12.48.dc4aae42bc42f5a2cca5688cb02e01ec.pdf
Garbossa, L. H. P., \& Pinheiro, A. (2015). Vazões de referência para gestão de bacias hidrográficas rurais e urbanas sem monitoramento. Revista de Gestão de Água da América Latina, 12(1), 43-52. http:/ / dx.doi.org/10.21168/rega.v12n1.p43-52.

Garbossa, L. H. P., Souza, R. V., Campos, C. J. A., Vanz, A., Vianna, L. F. N., \& Rupp, G. S. (2017). Thermotolerant coliform loadings to coastal areas of Santa Catarina (Brazil) evidence the effect of growing urbanisation and insufficient provision of sewerage infrastructure. Environmental Monitoring and Assessment, 189(1), 27. PMid:28000123. http://dx.doi.org/10.1007/s10661-016-5742-0.

Gillson, J. (2011). Freshwater flow and fisheries production in estuarine and coastal systems: where a drop of rain is not lost. Reviews in Fisheries Science, 19(3), 168-186. http://dx.doi.org/10.1 080/10641262.2011.560690.

Gisen, J. I. A., Savenije, H. H. G., \& Nijzink, R. C. (2015a). Revised predictive equations for salt intrusion modelling in estuaries. Hydrology and Earth System Sciences, 19(6), 2791-2803. http:/ /dx.doi. org/10.5194/hess-19-2791-2015.

Gisen, J. I. A., Savenije, H. H. G., Nijzink, R. C., \& Wahab, A. K. (2015b). Testing a 1-D analytical salt intrusion model and its predictive equations in Malaysian estuaries. Hydrological Sciences Journal, 60(1), 156-172. http://dx.doi.org/10.1080/02626667.2 014.889832 .

Guarda, A. (2012). Gestão urbana: projeção da população flutuante. In Anais do Congresso Brasileiro de Cadastro Técnico Multifinalitário (COBRAC 2012). Florianópolis: UFSC.

Haggard, B. E., Stanley, E. H., \& Storm, D. E. (2005). Nutrient retention in a point-source-enriched stream. Journal of the North American Benthological Society, 24(1), 29-47. http://dx.doi. org/10.1899/0887-3593(2005)024<0029:NRIAPS>2.0.CO;2.

Instituto Chico Mendes de Conservação da Biodiversidade - ICMBio. (2011). Processo Administrativo no 02078.000040/2011-44. Brasília.

Kennish, M. J. (2002). Environmental threats and environmental future of estuaries. Environmental Conservation, 29(1), 78-107. http:/ / dx.doi.org/10.1017/S0376892902000061.

Kimmerer, W. J. (2002). Physical, biological, and management responses to variable freshwater inflow into San Francisco Estuary. Estuaries, 25(6), 1275-1290. http://dx.doi.org/10.1007/BF02692224.

McLusky, D. S., \& Elliott, M. (2006). The estuarine ecosystem: ecology threats and management (3rd ed., 214 p.). Oxford: Oxford University Press.

Mekonnen, M. M., \& Hoekstra, A. Y. (2018). Global Anthropogenic phosphorus loads to freshwater and associated grey water footprints and water pollution levels: a high-resolution global study. Water Resources Research, 54(1), 345-358. http://dx.doi. org/10.1002/2017WR020448. 
Miranda, L. B., \& Castro, B. M., \& Kjerfve, B. (2002). Principios de oceanografia física de estuários (424 p.). São Paulo: Editora da Universidade de São Paulo.

Montagna, P. A., Palmer, T. A., \& Pollack, J. B. (2003). Hydrological change and estuarine dynamics. Switzerland: Springer. 94p.

Morrison, G., Greening, H., \& Yates, K. K. (2011). Management case study: Tampa Bay, Florida. In E. Wolanski \& D. McLusky (Ed.). Treatise on estuarine and coastal science (Vol. 11, pp. 31-76). Amsterdam: Elsevier. http://dx.doi.org/10.1016/B978-0-12-374711-2.01104-9.

Nguyen, A. D., Savenije, H. H. G., Pham, D. N., \& Tang, D. T. (2008). Using salt intrusion measurements to determine the freshwater discharge distribution over the branches of a multi-channel estuary: the Mekong Delta case. Estuarine, Coastal and Shelf Science, 77(3), 433-445. http://dx.doi.org/10.1016/j.ecss.2007.10.010.

Peel, M. C., Finlayson, B. L., \& Mcmahon, T. A. (2007). Updated world map of the Köppen-Geiger climate classification. Hydrology and Earth System Sciences, 11(5), 1633-1644. http://dx.doi.org/10.5194/ hess-11-1633-2007.

Pereira Filho, J., \& Rörig, L. R. (2016). Balanço de massa para nutrientes inorgânicos ( $\mathrm{N}$ e P) no estuário do rio Itajaí-Açu, SC. Revista Brasileira de Recursos Hídricos, 21(1), 168-187. http:/ /dx.doi. org/10.21168/rbrh.v21n1.p168-187.

Perez, A. B. A., Rodrigues, C. J., \& Farias, M. A. (2017). Biogeoquímica do fósforo no estuário do rio Papaquara. In Anais do XX Simpósio Brasileiro de Recursos Hídricos. Florianópolis: ABRH. Retrieved in 2021, April 15, from http://abrh.s3.amazonaws.com/Eventos/ Trabalhos/60/PAP021971.pdf

Pinto-Coelho, R. M., \& Havens, K. (2015). Crise nas águas (162 p.). Belo Horizonte: Recóleo.

Prosul. (2012). Projeto básico do sistema de disposição oceânica- S.D.O. de efluentes tratados da praia do Campeche emissários: terrestre e submarino (Vol. I: Memorial de projeto estudos demográficos: área de projeto atualização, 148 p.). Florianópolis: Companhia Catarinense de Água e Saneamento (CASAN).

Rabalais, N. N., Díaz, R. J., Levin, L. A., Turner, R. E., Gilbert, D., \& Zhang, J. (2010). Dynamics and distribution of natural and human-caused hypoxia. Biogeosciences, 7(2), 585-619. http://dx.doi. org/10.5194/bg-7-585-2010.

Ramos, A. M., Santos, L. A. R., \& Fortes, L. T. G. (2009). Normais climatológicas do Brasil, 1961-1990 (465 p.). Brasília: Instituto Nacional de Meteorologia, Ministério da Agricultura, Pecuária e Abastecimento-MAPA.

Rodrigues, C. J. (2016). Águas de Carijós: passado, presente e futuro e seus impactos (Dissertação de mestrado). Universidade Federal de Santa Catarina, Florianópolis.

Santa Catarina. (2006). Regionalização de vazões das bacias hidrográficas estaduais do estado de Santa Catarina (Vol. 1, 141 p.). Retrieved in
2021, April 5, from http://www.aguas.sc.gov.br/jsmallfib_top/ DHRI/Legislacao/estudo_de_regionalizacao_hidrologica.pdf

Savenije, H. H. G. (1986). A one-dimensional model for salinity intrusion in alluvial estuaries. Journal of Hydrology, 85(1-2), 87-109. http://dx.doi.org/10.1016/0022-1694(86)90078-8.

Savenije, H. H. G. (2005). Salinity and tides in alluvial estuaries (194 p.). Amsterdam: Elsevier.

Savenije, H. H. G. (2020). Salinity and tides in alluvial estuaries: applications. Retrieved in 2020, June 8, from https: / / salinityandtides. com/applications/

Scherner, F., Horta, P. A., Oliveira, E. C., Simonassi, J. C., HallSpencer, J. M., Chow, F., Nunes, J. M., \& Pereira, S. M. (2013). Coastal urbanization leads to remarkable seaweed species loss and community shifts along the SW Atlantic. Marine Pollution Bulletin, 76(1-2), 106-115. PMid:24090881. http://dx.doi.org/10.1016/j. marpolbul.2013.09.019.

Silva, A. R. (2015). Avaliação da qualidade ambiental e do processo de eutrofizaçãa na bacia hidrográfica do Papaquara, Itha de Santa Catarina, SC (Dissertação de mestrado). Universidade Federal de Santa Catarina, Florianópolis.

Silva, A. R., Fonseca, A. L., Monteiro, J. P. P. G., \& Santos, L. C. A. (2018). A gestão e monitoramento das águas: uma abordagem das legislações em Portugal e Brasil. Revista Brasileira de Geografia Física, 11(4), 1512-1525. http://dx.doi.org/10.26848/rbgf.v11.4.p1512-1525.

Silva, A. R., Fonseca, A. L., Rodrigues, C. J., \& Beltrame, Â. V. (2016). Application of ecological indicators in coastal watershed under high pressure during summer period. Revista Brasileira de Recursos Hidricos, 21(3), 537-548. http://dx.doi.org/10.1590/2318-0331.011615106.

Silveira, G. L., Tucci, C. E. M., \& Silveira, A. L. L. (1998). Quantificação de vazão em pequenas bacias sem dados. Revista Brasileira de Recursos Hídricos, 3(3), 111-131. http://dx.doi. org/10.21168/rbrh.v3n3.p111-131.

Simonassi, J. C., Hennemann, M. C., Talgatti, D., \& Marques Junior, A. N. (2010). Nutrient variatin and coastal water quality of Santa Catarina island, Brazil. Biotemas, 23, 211-223. http://dx.doi. org/10.5007/2175-7925.2010v23n1p211.

Souza, M. M., \& Gastaldini, M. C. C. (2014). Avaliação da qualidade da água em bacias hidrográficas com diferentes impactos antrópicos. Engenharia Sanitaria e Ambiental, 19(3), 263-274. http://dx.doi. org/10.1590/S1413-41522014019000001097.

Steinwandter, B. R. (2019). Laudo pericial. Ação Civil Pública no $5022777-$ 48.2015.4.04.7200/SC (141 p.). Florianópolis.

Stumm, W., \& Morgan, J. J. (1996). Aquatic chemistry: chemical equilibria and rates in natural waters (1021 p.). Hoboken: John Wiley \& Sons.

Testa, J. M., \& Kemp, W. M. (2011). Oxygen: dynamics and biogeochemical consequences. In E. Wolanski \& D. McLusky 
(Eds.), Treatise on estuarine and coastal science (Vol. 5). Amsterdam: Elsevier. http://dx.doi.org/10.1016/B978-0-12-374711-2.00505-2.

Truccolo, E. C., Franco, D., \& Schettini, C. A. F. (2006). The low frequency sea level oscillations in the northern coast of Santa Catarina, Brazil. Journal of Coastal Research, 39, 547-552.

Tucci, C. E. M. (2002). Hidrologia: ciência e aplicação (943 p.). Porto Alegre: ABRH.

Van Der Burgh, P. (1972). Ontwikkeling van een methode voor het voorspellen van zoutverdelingen in estuaria, kanalen en zeeen. Rijkswaterstaat Rapport, 10-72.

Van Drecht, G., Bouwman, A. F., Harrison, J., \& Knoop, J. M. (2009). Global nitrogen and phosphate in urban wastewater for the period 1970 to 2050. Global Biogeochemical Cycles, 23(4), 1-19. http://dx.doi.org/10.1029/2009GB003458.

Willmott, C. J., Robeson, S. M., \& Matsuura, K. (2011). A refined index of model performance. International Journal of Climatology, 32(13), 2088-2094. http://dx.doi.org/10.1002/joc.2419.

Wolanski, E., \& Elliott, M. (2015). Estuarine ecohydrology: an introduction (321 p.). Amsterdam: Elsevier.

Zhang, E., Savenije, H. H. G., Wu, H., Kong, Y., \& Zhu, J. (2011). Analytical solution for salt intrusion in the Yangtze Estuary, China. Estuarine, Coastal and Shelf Science, 91(4), 492-501. http://dx.doi. org/10.1016/j.ecss.2010.11.008.

\section{Authors contributions}

Claudinei José Rodrigues: Conceptualization (Lead), Data curation (Lead), Formal analysis (Equal), Investigation (Equal), Methodology (Equal), Writing-original draft (Lead).

Davide Franco: Conceptualization (Supporting), Formal analysis (Equal), Investigation (Equal), Methodology (Equal), Supervision (Equal), Writing-review \& editing (Equal).

Alessandra Larissa D'Oliveira Fonseca: Conceptualization (Supporting), Formal Analysis (Supporting), Metodology (Supporting), Investigation (Supporting), Supervision (Equal), Writing-review \& editing (Equal).

Nei Kavaguichi Leite: Investigation (Supporting), Supervision (Equal), Writing-review \& editing (Equal).

Luis Hamilton Pospissil Garbossa: Investigation (Supporting), Writing-review \& editing (Equal).

Aichely Rodrigues da Silva: Investigation (Supporting), Writingreview \& editing (Equal).

Editor-in-Chief: Adilson Pinheiro

Associated Editor: Fernando Mainardi Fan 